\title{
Model Analisis Kebijakan Pendidikan
}

\author{
Asep Abdul Aziz ${ }^{1}$, Rida Nurfarida ${ }^{2}$, Nurti Budiyanti ${ }^{3 *}$, Qiqi Yuliati Zakiah ${ }^{4}$ \\ ${ }^{124}$ Universitas Islam Negeri Sunan Gunung Djati Bandung, Indonesia \\ ${ }^{3}$ Universitas Pendidikan Indonesia, Indonesia
}

nurtibudiyanti@upi.edu*

\begin{tabular}{|c|c|}
\hline & Abstract \\
\hline ARTICLE INFO & $\begin{array}{l}\text { Education was very important in human intelligence. This article aimed to } \\
\text { describe the model of education policy analysis. This research used a qualitative }\end{array}$ \\
\hline Article history: & approach in library studies. The results showed that the education policy model \\
\hline Received & consisted of three things namely (1) formulation model, (2) analysis model, and \\
\hline $\begin{array}{l}\text { November 08, } \\
2020\end{array}$ & $\begin{array}{l}\text { (3) implementation model. The formulation model consists of institutional } \\
\text { models, system models, mixed investigation models, process models, elite theory }\end{array}$ \\
\hline Revised & models, rational models, critical models, strategic models, deliberative models. \\
\hline $\begin{array}{l}\text { November } 29 \text {, } \\
\quad 2020\end{array}$ & $\begin{array}{l}\text { Meanwhile, the education policy analysis model consists of a prospective, } \\
\text { retrospective, and integrative models. The implementation model consists of top- }\end{array}$ \\
\hline Accepted & down and bottom-up models. The results of education policy analysis used in \\
\hline $\begin{array}{l}\text { December 05, } \\
2020\end{array}$ & $\begin{array}{l}\text { Indonesia use more political policy analysis models based on political } \\
\text { assumptions. }\end{array}$ \\
\hline
\end{tabular}

Published by

Keywords: Educational Model, Policy of Educational Model, Policy Education

Website

Lembaga Penelitian dan Pengabdian Kepada Masyarakat

Institut Agama Islam Negeri Metro

http://e-journal.metrouniv.ac.id/index.php/tapis/index

This is an open access article under the CC BY SA license

https://creativecommons.org/licenses/by-sa/4.0/

\section{PENDAHULUAN}

Pendidikan merupakan hal yang sangat penting untuk dibicarakan sebab biasanya kecerdasan manusia dilihat dari seberapa tinggi seseorang tersebut mengenyam pendidikan. Dengan adanya pendidikan, manusia juga dapat mencapai kebutuhan hidupnya dengan berbagai cara. Dalam hal ini pemerintah juga tidak serius dalam menggalakkan pendidikan, terbukti dengan adanya salah satu peraturan yang mengatur pendidikan yang tertuang dalam UUD 1945 pasal 31 ayat 1,2 an 3 (Iskandar, 2019; Suhono \& Sari, 2020; Irianisyah, 2020). Dalam hal ini jelas terlihat bahwa pendidikan dipengaruhi oleh hasil dari suatu kebijakan yang ditetapkan oleh pemerintah. Kebijakan adalah aturan tertulis yang merupakan keputusan formal organisasi, yang bersifat mengikat, yang mengatur perilaku dengan tujuan untuk menciptakan tata nilai baru dalam masyarakat (Costantina, 2018). Dalam hal ini, kebijakan akan menjadi rujukan utama para anggota organisasi atau anggota masyarakat dalam berprilaku (Dunn 2003). Kebijakan pada umumnya bersifat problem solving dan proaktif. Berbeda dengan Hukum (Law) dan Peraturan (Regulation), kebijakan lebih adaptif dan interpratatif, meskipun kebijakan juga mengatur "apa yang boleh, dan apa yang tidak boleh". Kebijakan juga diharapkan dapat bersifat umum tetapi tanpa menghilangkan ciri lokal yang spesifik (Darwis 2013). Kebijakan harus memberi peluang diinterpretasikan sesuai kondisi spesifik yang ada.

Kebijakan sering dipergunakan dalam konteks tindakan-tindakan atau kegiatankegiatan yang dilakukan oleh para aktor dan institusi-institusi pemerintah serta perilaku pada umumnya. Makna kebijakan juga sering dikonotasikan dengan sebagai politik karena membawa konsekwensi politis dan perilaku politik. Dengan makna lain kebijakan adalah a means to an end, alat untuk mencapai sebuah tujuan. Kebijakan publik pada akhirnya menyangkut pencapaian tujuan publik. Menurut Lester dan Stewart, studi kebijakan publik kini telah

Doi http://doi.org/10.32332/tapis.v4i2.2575

ISSN Print 2579-3233; Online 2580-068X

Volume 4 Number 2, December 2020, page 192-201 
meliputi berbagai tahap seperti terangkum dalam lingkaran kebijakan publik (public cycle) yang meliputi tahapan yaitu 1) agenda setting, policy formulation, 3) policy implementation, 4) policy evaluation, 5) policy change, dan 6) policy termination (Lester \& Stewart, 2000; Arlita dkk., 2020). Sementara menurut Dunn tahap dalam melakukan policy melalui lima langkah yaitu 1) penyusunan agenda, 2) melalui formulasi kebijakan, 3) adopsi kebijakan, 4) implementasi kebijakan, 5) penilaian/ evaluasi kebijakan (Dunn, 2003). Kelima tahapan ini menjadi berurutan secara hirarkhi, kesemuanya tahapan perlu dikelola dan dikontrol oleh pembuat yang sekaligus pelaksana kebijakan publik. Langkah-langkah membuat kebijakan di atas memberikan makna bahwa sebuah kebijakan harus dilakukan secara bertahap dan melalui sebuah proses yang perencanaa, implementasi dan evaluasi.

Realita kini, kebijakan tidak didasai oleh kelima nilai di atas, maka ini menjadi sebuah pengingat bagi peneliti sebagai praktisi serta pemangku kebijakan agar dapat menyelesaikan berbagai persoalan melalui formulasi kebijakan yang baik. Berdasarkan kajian terdahulu, konsep analisis kebijakan digambarkan secara umum dalam berbagai disiplin bidang ilmu pengetahuan (Bintari dkk., 2016). Perlu adanya fokus pembahasan mengenai pendidikan secara khusus. Analsisis model kebijakan sangat penting untuk difahami agar kebijakan yang dihasilkan dapat mengantarkan keberhasilan tujuan pendidikan. Terdapat berbagai model formulasi kebijakan dalam pendidikan untuk memecahkan permasalahan yang ada. Dengan demikian, penulis merasa penting untuk menuangkan artikel yang berjudul tentang model formulasi kebijakan pendidikan, agar dapat memahami berbagai model yang ada dan dapat diaplikasikan dalam dunia pendidikan.

\section{METODE}

Metode penelitian ini menggunakan pendekatan kualitatif. Model penelitian ini menggunakan library research, dengan analisis inductive deduktif yang berasal dari beberapa analsisis literature (O'Dwyer \& Bernauer, 2013; Moser \& Korstjens, 2018). Penelitian ini disebut sebagai penelitian kepustakaan (library research) sebagai proses understanding dari data teks tersebut, penulis kemudian menginterpretasikannya menggunakan metode deskripsi analisis, yakni dimulai dengan pengumpulan data secara sistematis dan konsisten, yang kemudian dianalisis, diseleksi serta digabungkan untuk kemudian diambil kesimpulan menggunakan analisis yang deduktif, dari masalah yang bersifat umum kemudian diambil kesimpulan bersifat khusus. Sedangkan sumber data yang dipergunakan yaitu data primer sebagai penguat dan pelengkap data-data yang dirasa valid dan data sekunder yaitu berupa buku-buku dan jurnal-jurnal yang relevan dalam judul penelitian. Sumber data yang digunakan adalah berasal dari Jurnal dan buku diantaranya di tulis oleh Azis dkk., 2017. dkk., 2019, Parsons, Wayne. 2006, Sabri dkk., 2013, Muhdi dkk., 2017, dan sumber lainnya yang relevan. Sedangkan metode analisis dan interpretasi data yang digunakan oleh peneliti mengacu pada langkah-langkah analisis yang diajukan oleh Creswell (2016), Pertama, Memproses dan menyiapkan data untuk ditinjau; Kedua, membaca seluruh data; Ketiga, Mulai mengkode semua data penelitian; Keempat, mendeskripsikan kategori dan pengaturan tema yang akan dianalisis; Kelima, Menyajikan laporan naratif kualitatif, dan Keenam, Membuat interpretasi dalam penelitian kualitatif.

\section{HASIL DAN PEMBAHASAN \\ Model Perumusan Kebijakan Pendidikan -Model Kelembagaan (institusionalisme)}

Model kelembagaan berpendapat bahwa tugas membuat kebijakan publik adalah tugas pemerintah, jadi apapun yang telah dibuat pemerintah, dengan cara apapun adalah kebijakan publik. Model ini mendasarkan kepada fungsi-fungsi kelembagaan dari pemerintah, di setiap sektor dan tingkat, di dalam perumusan kebijakan. Menurut Dye lembaga pemerintah memberikan kebijakan dengan tiga ciri utama yaitu (1) lembaga Negara itu memberikan pengesahan (legitimasi), (2) kebijakan Negara itu bersifat universal dalam arti bahwa hanya kebijakan-kebijakan negara yang dapat disebarluaskan, (3) hanya pemerintah yang memegang hak monopoli untuk memaksakan secara sah kebijakan kepada masyarakat (Dye 2011, 20). 
dengan demikian model kelembagaan ini merupakan model yang bisa diterapkan dalam membuat kebijakan pendidikan pada tataran pemerintahan.

\section{-Model Sistem}

Paine dan Naumes menawarkan suatu model proses pembuatan kebijakan merujuk pada model sistem yang dikembangkan oleh David Easton. Model ini menurut Paine dan Naumes merupakan model deskripitif karena lebih berusaha menggambarkan senyatanya yang terjadi dalam pembuatan kebijakan. Menurut Paine dan Naumes, model ini disusun hanya dari sudut pandang para pembuat kebijakan. Dalam hal ini para pembuat kebijakan dilihat perannya dalam perencanaan dan pengkoordinasian untuk menemukan pemecahan masalah yang akan (1) menghitung kesempatan dan meraih atau menggunakan dukungan internal dan eksternal, (2) memuaskan permintaan lingkungan, dan (3) secara khusus memuaskan keinginan atau kepentingan para pembuat kebijakan itu sendiri.

Dengan merujuk pada pendekatan sistem yang ditawarkan oleh Easton, Paine dan Naumes menggambarkan model pembuatan kebijakan sebagai interaksi yang terjadi antara lingkungan dengan para pembuat kebijakan dalam suatu proses yang dinamis. Model ini mengasumsikan bahwa dalam pembuatan kebijakan terdiri dari interaksi yang terbuka dan dinamis antar para pembuat kebijakan dengan lingkungannya. Interaksi yang terjadi dalam bentuk keluaran dan masukan (inputs dan outputs) (Toha \& Hilmy, 2020). Keluaran yang dihasilkan oleh organisasi pada akhirnya akan menjadi bagian lingkungan dan seterusnya akan berinteraksi dengan organisasi. Paine dan Naumes memodifikasi pendekatan ini dengan menerapkan langsung pada proses pembuatan kebijakan sebagai beriku:

\section{Gambar 1. Model Paine dan Naumes}

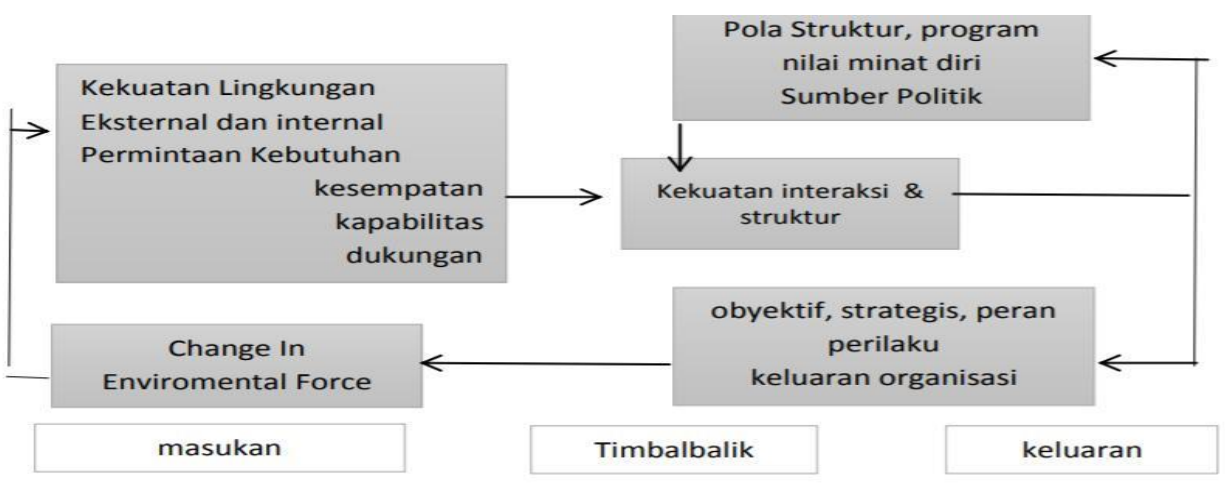

Menurut model sistem, kebijakan politik dipandang sebagai tanggapan dari suatu sistem politik terhadap tuntutan-tuntutan yang timbul dari lingkungan yang merupakan kondisi atau keadaan yang berada diluar batas-batas politik. Kekuatan-kekuatan yang timbul dari dalam lingkungan dan mempengaruhi sistem politik dipandang sebagai masukan-masukan (inputs) sebagai sistem politik, sedangkan hasil-hasil yang dikeluarkan oleh sistem politik yang merupakan tanggapan terhadap tuntutan-tuntutan tadi dipandang sebagai keluaran (outputs) dari sistem politik. Untuk mengubah tuntutan-tuntutan menjadi hasil-hail kebijakan (kebijakankebijakan publik), suatu sistem harus mampu mengatur penyelesaian-penyelesaian pertentangan atau konflik dan memberlakukan penyelesaian-penyelesaian ini pada pihak yang bersangkutan, oleh karena suatu sistem dibangun berdasarkan elemen-elemen yang mendukung sistem tersebut dan hal ini bergantung pada interaksi antara berbagai subsistem, maka suatu sistem akan melindungi dirinya melalui tiga hal, yakni: 1) menghasilkan output yang secara layak memuaskan, 2) menyandarkan diri pada ikatan-ikatan yang berakar dalam sistem itu sendiri, dan 3) menggunakan atau mengancam untuk menggunakan kekuatan (penggunaan otoritas). Dengan demikian, model sistem ini jika di aplikasikan dalam dunia pendidikan, perlu adanya keterlibatan masyarakat secara luas, untuk memetakan permasalahan yang timbul sehingga analisis kebijakan yang dikeluarkan dalam menjadi problem solving yang tepat dan bijak. 


\section{-Model Penyelidikan Campuran (Mixed Scanning)}

Model yang telah dipaparkan sebelumnya, yakni model sistem, model kelembagaan pada dasarnya mempunyai keunggulann dan kelemahannya masing-masing, oleh karena itu, dalam rangka mencari model yang lebih komprehensif, Amitai Etzioni mencoba membuat gabungan dengan menyarankan penggunaan mixed scanning (Ismail \& Sofwani, 2016). Pada dasarnya ia menyetujui model rasional, namun dalam beberapa hal ia juga mengkritiknya. Demikian juga, ia melihat pula kelemahan-kelemahan model pembuatan keputusan inkremental. Etzioni memperkenalkan mixed scanning sebagai suatu pendekatan terhadap pembuatan keputusan yang memperhitungkan keputusan-keputusan pokok dan inkremental (Mulyana dkk., 2019), menetapkan proses-proses pembuat kebijakan pokok urusan tinggi yang menentukan petunjuk-petunjuk dasar, proses-proses yang mempersiapkan keputusan-keputusan pokok dan menjalankannya setelah keputusan itu tercapai.

Strategi penyelidikan campuran (mixed scanning strategy) menggunakan elemenelemen dari dua pendekatan dengan menggunakan dua kamera, yakni sebuah kamera dengan sudut pandang lebar yang mencakup semua bagian luar angkasa, tetapi tidak sangat terperinci dan kamera yang kedua membidik dengan tepat daerah-daerah yang diambil oleh kamera pertama untuk mendapatkan penyelidikan yang mendalam. Menurut Etzioni, daerah-daerah tertentu mungkin luput dari penyelidikan campuran ini, namun pendekatan ini masih lebih baik dibandingkan dengan inkrementalisme yang mungkin tidak dapat mengamati tempat-tempat yang kacau di daerah-daerah yang tidak dikenal. Dalam penyelidikan campuran para pembuat keputusan dapat memanfaatkan teori-teori rasional komprehensif dan inkremental dalam situasisituasi yang berbeda. Dalam beberapa hal, mungkin pendekatan inkrementalisme mungkin telah cukup memadai namun dalam situasi yang lain dimana masalah yang dihadapi berbeda, maka pendekatan yang lebih cermat dengan menggunakan rasional komprehensif mungkin jauh lebih memadai. Dengan demikian, model penyelidikan campuran ini merupakan model yang bisa diterapkan dalam dunia pendidikan yang berusaha untuk menetapkan berbagai keputusan secara rasional dan inkremental.

-Model Proses

Model proses berasumsi bahwa politik merupakan sebuah aktivitas sehingga mempunyai proses. Untuk itu, kebijakan publik merupakan juga proses politik yang menyertakan rangkaian kegiatankegiatan secara berurutan : (1) identifikasi permasalahan, (2) menata agenda, (3) perumusan proposal kebijakn, (4) legitimasi kebijakan, (5) implementasi kebijkan, (6) evaluasi kebijakan (Dye, 2011). Dengan demikian penulis berpendapat bahwa model proses harus senantiasa diterapkan dalam dunia pendidikan, agar kebijakan yang diberikan mengikuti alur yang ditetapkan dalam menghasilkan kebijakan yang baik dan tepat.

\section{-Model Teori Elite}

Teori elite berkembang dari teori politik elit-massa yang melandaskan diri pada asumsi bahwa di dalam setiap masyarakat pasti terdapat dua kelompok, yaitu pemegang kekuasaan (elit) dan yang tidak memegang kekuasaan (massa). Teori ini beranggapan bahwa sedemokratis apapun selalu ada bias di dalam formulasi kebijakan, karena pada akhirnya kebijakan-kebijakan yang dilahirkan merupakan preferensi politik dari para elit. Dalam model elite lebih banyak mencerminkan kepentingan dan nilai-nilai elit dibandingkan dengan memperhatikan tuntutantuntutan rakyat banyak (Masyitoh dkk., 2020), sehingga perubahan kebijakan publik hanyalah dimungkinkan sebagai suatu hasil dari merumuskan kembali nilai-nilai elite tersebut yang dilakukan oleh elite itu sendiri. Dalam model ini ada 3 lapisan kelompok sosial: 1. Lapisan atas, dengan jumlah yang sangat kecil (elit) yang selalu mengatur. 2. Lapisan tengah adalah pejabat dan administrator. 3. Lapisan bawah (massa) dengan jumlah yang sangat besar sebagai yang diatur. Dengan demikian penulis berpendapat bahwa isu kebijakan yang akan masuk agenda perumusan kebijakan dalam dunia pendidikan merupakan kesepakatan dan juga hasil konflik yang terjadi di antara elit politik sendiri. Sementara masyarakat tidak memiliki kekuatan untuk mempengaruhi dan menciptakan opini tentang isu kebijakan yang seharusnya menjadi agenda politik di tingkat atas, sementara birokrat/administrator hanya menjadi mediator bagi jalannya informasi yang mengalir dari atas ke bawah. Untuk itu perlu adanya sikap bijak dalam menentukan kebijakan agar dirasakan manfaatnya untuk kepentingan umum.

\section{5}




\section{-Model Rasional}

Mengedepankan gagasan bahwa kebijakan publik sebagai perolehan sosial maksimum (maximum social gain) yang berarti pemerintah sebagai pembuat kebijakan harus memilih kebijakan yang memberikan manfaat optimum bagi masyarakat. Model rasional memberikan preskripsi berbagai prosedur pengambilan keputusan yang akan menghasilkan pilihan cara yang paling efisien untuk mencapai tujuan kebijakan Teori-teori rasionalis berakar dalam aliran-aliran pemikiran positifisme dan rasionalisme jaman pencerahan yang berusaha untuk mengembangkan pengetahuan yang ilmiah untuk meningkatkan kondisi hidup manusia. Ide-ide ini didasarkan pada keyakinan bahwa berbagai permasalahan sosial seharusnya diselesaikan melalui cara yang ilmiah dan rasional, melalui pengumpulan segala informasi yang relevan dan berbagai alternatif solusi, dan kemudian memilih alternatif yang dianggap terbaik. Dengan demikian penulis berpendapat bahwa model rasional menyimpulkan bahwa berbagai keputusan publik pada prakteknya tidak memaksimalkan manfaat di atas beban, tetapi hanya cenderung untuk memenuhi kriteria yang ditetapkan oleh para pengambil keputusan untuk diri mereka sendiri dalam masalah yang sedang menjadi perhatian sebagai sesuatu yang muncul dari hakekat rasionalitas manusia yang terbatas.

\section{-Model Inkrimentalis}

Model ini merupakan kritik terhadap model rasional. Model inkrimentalis berpendapat bahwa para pembuat kebijakan tidak pernah melakukan proses seperti yang disyaratkan oleh pendekatan rasional karena mereka tidak cukup waktu, intelektual, maupun biaya ada kekhawatiran muncul dampak yang tidak diinginkan akibat kebijakan yang belum pernah dibuat sebelumnya. Model ini mencoba untuk menyesuaikan dengan realitas kehidupan praktis dengan mendasarkan pada pluralitas dan demokrasi, maupun keterbatasan-keterbatasan kemampuan manusia (Dye, 2011). Landasan pokok rasional model ini adalah bahwa perubahan inkrimental memberikan tingkat maksimal keamanan dalam proses perubahan kebijakan. Semua pengetahuan yang bisa dipercaya didasarkan pada acara satu-satunya untuk mengambil keputusan tanpa menimbulkan resiko dengan melanjutkan kebijakan sesuai dengan arah tujuan kebijakan lama membatasi pertimbangan-pertimbangan kebijakan alternatif dengan kebijakankebijakan yang secara relatif mempunyai tingkat perbedaan yang kecil dengan kebijakan sekarang yang berlaku. Dengan demikian, model kebijakan ini merupakan model yang tidak melakukan proses, sementara pendidikan memerlukan proses yang sangat lama dan berkelanjutan, jadi hemat peneliti model ini kurang tepat diterapkan dalam dunia pendidikan.

\section{-Model Strategis}

Disebut strategis adalah intinya pendekatan ini menggunakan rumusan runtutan perumusan strategis sebagai basis perumusan kebijakan. Perumusan makna strategis yaitu upaya yang di disiplinkan untuk membuat keputusan dan tindakan penting yang membentuk dan memandu bagaimana menjadi organisasi (atau entitas lainya) apa yang dikerjakan organisasi, dan mengapa organisasi mengerjakan hal seperti itu. Perencanaan strategis mensyaratkan pengumpulan informasi secara luas, eksplorasi alternatif, dan menekankan implikasi masa depan dengan keputusan sekarang. Perencanaan strategis lebih memfokuskan pada identifikasi dan pemecahan isu-isu, lebih menekankan kepada penilaian terhadap lingkungan luar dan di dalam organisasi, dan berorientasi pada tindakan. Dengan demikian, model strategis merupakan sebuah model yang dapat diterapkan dalam dunia pendidikan, karena pada hakikatnya kebijakan yang dibuat harus berdasar pada alternatif pemecahan masalah yang terjadi dilapangan, sehingga ketepatan strategi dapat membawa perbaikan di kemudian hari.

\section{-Model Deliberatif}

Pada intinya kebijakan publik yang dibuat oleh pemerintah harus merupakan pilihan publik yang menjadi pengguna (Beneficiaries atau consumer dalam konsep ekonomi). Dengan demikian, proses formulasi kebijakan publik melibatkan publik melalui kelompok-kelompok kepentingan. Secara umum, ini adalah konsep formulasi kebijakan publik yang paling demokratis karena memberi ruang luas kepada publik untuk mengontribusikan pilihanpilihannya kepada pemerintah sebelum pengambilan keputusan (Parsons, 2006). Proses analisis kebijakan publik model "musyawarah" ini jauh berbeda dengan model-model teknokratik karena peran analisis kebijakan hanya sebagai fasilitator agar masyarakat menemukan sendiri 
keputusan kebijakan atas dirinya sendiri. Model deliberatif ini juga dikenal sebagai model kebijakan argumentatif, yang merupakan model perumusan kebijakan dengan melibatkan argumentasi-argumentasi dari pihak, atau dengan mempelajari argumentasi-argumentasi tertulis dari berbagai pihak, sebagai dasar perumusan. Model argumentatif atau deliberatik dikembangkan dari keyakinan kaum Shopia di Yunani Kuno yang menyakini bahwa kebenaran dapat dicapai melalui diskusi dan perdebatan yang intens di antara para pihak. Di dalam model deliberatif dibutuhkan peran dari publik, tanpa publik proses kebijakan akan kering dan sangat berbau teknokratis, maka penulis berpendapat bahwa model deliberatif merupakan model yang bisa digunakan oleh pemerintah dalam menentapkan serta merumuskan kebijakan yang tepat dengan melipatkan stakeholder yang ada dalam dunia pendidikan.

\section{-Model Analisis Kebijakan Pendidikan}

William Dunn, sebagaimana Nanang Fatah membuat satu pengertian tentang analisis kebijakan dengan menyatakan sebagai suatu disiplin ilmu sosial terapan melalui metode inkuiri dan argumentasi berganda dalam rangka menghasilkan dan mendayagunakan informasi kebijakan sesuai dengan suatu proses pengambilan keputusan yang bersifat politis, sehingga mampu memecahkan masalah dalam kebijakan (Khoiruddin, 2016).. Kegiatan analisis digunakan untuk melibatkan pemahaman dasar bagi manusia dalam upaya pemecahan masalah secara praktis. Tidak lagi hanya sebuah argumentasi sekedar rasional.

Ada tiga bentuk atau model analisis kebijakan menurut Dunn, yaitu model prospektif, retrospektif dan integratif. Model prospektif, yaitu model analisis kebijakan yang dilakukan sebelum sebuah kebijakan diterapkan. Atas pengertian tersebut, maka model ini lalu diidentikkan dengan model prediktif, atau dalam bahasa lain disebut dengan ramalan (forecasting). Karena sifatnya sebagai ramalan maka model melakukan prediktif kemungkinankemungkinan penerapan kebijakan yang akan diusulkan. Sedangkan model retrospektif, yaitu kebalikan dari model prospektif, bagaimana setelah kebijakan itu dilaksanakan. Model ini sering dinamakan model analisis evaluatif, menganalisa dampak terhadap pelaksanaan kebijakan. Adapun model integratif, yaitu memadukan kedua model di atas (Khoiruddin, 2016).. Model ini juga dinamakan dengan model analisis komprehenshif atau holistic, karena analisisnya dilakukan atas konsekuensi sebelum maupun sesudah suatu kebijakan dioperasikan. Model ini biasanya menggunakan teknik ramalan dan evaluasi secara integrative. Sejalan dengan tuntutan perkembangan jaman, kurikulum madrasah juga mendapat tantangan yang sangat berat. Apabila tidak melakukan reformulasi terhadap kurikulum pendidikan madrasah yang ada, maka keberadaan madrasah lambat laun akan ketinggalan, yang pada gilirannya ditingggalkan umat sebagai peminat pendidikan madrasah.

Pendidikan Islam sebenarnya telah berlangsung selama berabad-abad yang merupakan tradisi pembelajaran Islam sebagai sebuah akar. Bahkan pendidikan pesantren yang kemudian ada sistem madrasah telah banyak diakui sebagai karakteristik pendidikan asli Indonesia. Modernisasi madrasah dimulai sejak kedatangan penjajah dari bangsa Eropa, Belanda khususnya yang menerapkan sistem pendidikan klasikal, sebagian orang mengatakan pendidikan berbasis sekuler. Pendidikan pesantren dengan kurikulum pembelajarannya ilmuilmu naqliyah seperti al- qur'an, hadist, ilmu-ilmu tauhid, fiqh dan sejarah Nabi Muhammad serta mantiq yang dipelajari secara tradisional, dan dilakukan seadanya. Sistem hafalan menjadi primadona pembelajaran hampir semua pesantren, yang didalamnya tentu madrasah telah berjalan sejak pesantren itu ada hingga hari ini (Khoiruddin, 2016)., maka penulis mengambil kesimpulan bahwa model analisis kebijakan pendidikan yang terjadi saai ini memadukan analisiss prospektif, retrospektif dan integratif. Karena kebijakan dalam dunia pendidikan merupakan kebijakan serius untuk membangun perbaikan dalam dunia pendidikan secara komprehensif dan integratif.

-Model Pendekatan Implementasi Kebijakan Publik

Model pedekatan implementasi kebijakan publik menurut Lester dan Stewart dalam Agustino (2012) adalah dijelaskan adanya dua pendekatan guna memahami implementasi kebijakan, yaitu: "pendekatan top down dan bottom up. Istilah itu dinamakan dengan the commond and control approach (pendekatan control dan komando, yang mirip dengan top down appoarch)" dan the market approach (pendekatan pasar, yang mirip dengan bottom up 
approach). Masing-masing pendekatan mengajukan model-model kerangka kerja dalam membentuk keterkaitan antara kebijakan dan hasilnya (Bintari \& Pandiangan, 2016).

Berdasarkan penjelasan di atas maka dapat diketahui bahwa pendekatan top down dapat disebut sebagai pendekatan yang mendominasi awal perkembangan implementasi kebijakan, kemudian keputusannya diambil dari tingkat pusat. Implementasi kebijakan dengan pendekatan bottom up muncul sebagai kritik terhadap model pendekatan rasional. Menurut Smith dalam Islamy (2001) mengatakan bahwa implementasi kebijakan dipandang sebagai suatu proses atau alur. Model ini memandang proses implementasi kebijakan dari proses kebijakan adalah dari prespektif perubahan sosial dan politik, dimana kebijakan yang dibuat pemerintah bertujuan untuk mengadakan perbaikan atau perubahan dalam masyarakat sebagai kelompok sasaran (Meilina dkk., 2019). Dengan demikian, anggapan penulis berkenaan dengan penggunaan model implementasi kebijakan ini harus disesuaikan dengan tujuan serta kebutuhan yang hendak dicapai dan kedua pendekatan ini dalam di aplikasikan dalam dunia pendidikan.

\section{-Analisis Model Kebijakan Pendidikan di Indonesia}

Kebijakan dalam dunia pendidikan sering disebut dengan beberapa istilah yang hampir memiliki kesamaan.Diantara istilah itu adalah perencanaan pendidikan (educational planning), rencana induk tentang pendidikan (master plan of education), pengaturan pendidikan (educational regulatuion), kebijakan tentang pendidikan (policy of education). Beberapa istilah di atas memiliki perbedaan dan penggunaan yang berbeda pula (Azis, 2017).

Kebijakan pendidikan adalah menyangkut efisiensi dan efektifitas anggaran pendidikan (Sabri, 2013). Artinya kebijakan pada aspek proses dan implementasinya, dimana harus melihat sumber daya manusia, dana, fasilitas dan manfaat kebijakan (Muhdi dkk., 2017). Pendapat Devine yang dikutip oleh Munadi dan Barnawi bahwa kebijakan pendidikan memiliki empat dimensi kebijakan, yaitu dimensi normatif, struktural, konstituentif, dan teknis. Dimensi normatif terdiri atas nilai, standar, dan filsafat. Dimensi ini memaksa masyarakat untuk melakukan peningkatan dan perubahan melalui kebijakan pendidikan yang ada. Dimensi tersebut perlu dukungan dari dimensi struktural (Munadi \& Barnawi, 2011).. Dimensi ini berkaitan dengan ukuran pemerintah dan satu struktur organisasi, metode dan prosedur yang menegaskan dan mendukung kebijakan bidang pendidikan. Dimensi konstituentif terdiri dari individu, kelompok kepentingan dan penerima yang menggunakan kekuatan untuk proses kebijakan.

Sementara itu kebijakan pendidikan yang digunakan di Indonesia seperti yang diungkapkan oleh Yoyon yaitu lebih banyak mmenggunakan model analisis kebijakan politik yang didasarkan pada asumsi-asumsi politis. Hal ini bisa dilihat dari beberapa indikatorindikator. Pertama, ketidakjelasan dalam asumsi-asumsi yang digunakan terhadap permasalahan-permasalahan pendidikan. Kompleksitas dan heterogenitas, sifat dan situasi yang disebut sekolah selalu diidentikan dengan pendidikan. Sehingga tidak heran manakala membicarakan sistem pendidikan ternyata yang dibahas adalah sistem persekolahan.

Temuan dari penelitian ini adalah bahwa hasil analisis kebijakan pendidikan yang digunakan di Indonesia sebagian para praktisi mengatakan lebih banyak mmenggunakan model analisis kebijakan politik yang didasarkan pada asumsi-asumsi politis. Namun tidak semuanya demikian, banyak pula kebijakan pendidikan yang diputuskan berbasarkan analisis serta kebutuhan yang terjadi di lapangan. Untuk itu perlu strategi yang tepat dalam memetakan permasalahan yang terjadi, menganalisis berbagai faktor yang mempengaruhi, serta merumuskan beberapa alternatif pemecahan masalah yang tentunya disajikan dalam formulasi model anaslisis kebijakan pendidikan, sehingga kebijakan yang diberikan bukan hanya menguntungkan sebelah pihak, namuan kebijakan harus dapat memberikan manfaat untuk seluruh stakeholder yang terlibat dalam dunia pendidikan. Karena kebijakan dalam dunia pendidikan merupakan kebijakan yang perlu dianalisa dengan serius untuk membangun perbaikan dalam dunia pendidikan secara komprehensif dan integratif.

Kebijakan dalam pendidikan pun tidak terlepas dari nilai-nilai yang harus melekat pada seorang pembuat kebijakan, di antara nilai-nilai tersebut James Anderson menjabarkannnya menjadi lima nilai yakni nilai politik, nilai organisasi, nilai partai, nilai kebijakan, dan nilai ideologi. Kelima nilai ini akan sedikit banyak berpengaruh pada hasil keputusan. Salah satu 
nilai yang sangat berpengaruh akan bisa dilihat pada sisi evaluasi kebijakan (Dewi, 2017). Evaluasi dengan menggunakan sistem sistematis atau juga sering disebut sebagai evaluasi ilmiah merupakan evaluasi yang mempunyai kemampuan lebih baik untuk menjalankan evaluasi kebijakan dibandingkan dengan tipe evaluasi yang lain (Winarno, 2012). Menganilisis kebijakan pendidikan yang dianalisis ternyata kebijakan penyelenggaraan persekolahan. Akibatnya paradigma pendidikan yang universal dipandang secara sempit dan lebih banyak adaptif daripada inisiatif. Kedua, dalam melakukan analisis kebijakan pendidikan kurang kontekstual sebagai suatu kebijakan yang utuh dan terintegrasi secara empirical, evaluative, normative, predictive yang memberikan pedoman jelas bagi pengejawentahan formulasi, implementasi dan evaluasi kebijakan. Sebagai suatu produk, kebijakan pendidikan tidak diformulasikan berdasarkan elemen-elemen yang perlu diintegrasikan secara "sinergi" bukan sebagai komponen yang "terdikotomi". Artinya apakah rumusan-rumusan kebijakan pendidikan tersebut telah memenuhi kriteria kebijakan yang utuh atau masih ada butir-butir yang lepas dari ruang lingkupnya (Irianto, 2011; Saihu, 2020). Berkaitan dengan hal ini, penulis berpendapat bahwa tidak semua kebijakan pendidikan didasari oleh asumsi-asumsi politis, banyak pula kebijakan pendidikan yang diputuskan berbasarkan analisis serta kebutuhan yang terjadi di lapangan. Untuk itu perlu strategi yang tepat dalam memetakan permasalahan yang terjadi, menganalisis berbagai faktor yang mempengaruhi, serta merumuskan beberapa alternatif pemecahan masalah yang tentunya disajikan dalam formulasi model anaslisis kebijakan pendidikan, sehingga kebijakan yang diberikan bukan hanya menguntungkan sebelah pihak, namuan kebijakan harus dapat memberikan manfaat untuk seluruh stakeholder yang terlibat dalam dunia pendidikan.

\section{KESIMPULAN}

Pendidikan dipengaruhi oleh hasil dari suatu kebijakan yang ditetapkan oleh pemerintah, oleh sebab itu pemiliham model formulasi kebijakan yang tepat dapat mengahasilkan kebijakan yang baik. Terdapat beberapa model kebijakan pendidikan yang dibagi menjadi tiga bagian yakni (1) model perumusan, (2) model analisis dan (3) model implemetasi. Model perumusan terdiri dari model kelembagaan, model sistem, model penyelidikan campuran, model proses, model teori elit, model rasional, model inkrimentalis, model strategis, model deliberative. Sementara itu, model analisis kebijakan pendidikan terdiri dari model prospektif, retrospektif dan integrative. Adapun model implementasi terdiri dari model top down dan bottom up. Model analisis kebijakan pendidikan yang terjadi saai ini memadukan analisiss prospektif, retrospektif dan integratif.

\section{UCAPAN TERIMA KASIH}

Penulis mengucapkan terimaka kasih kepada seluruh dosen UIN Sunan Gunung Djati Bandung yang talah memberikan wawasan kepada penulis dalam mengkaji konsep pendidikan secara komprehensif dan integratif. Terlebih kajian tentang analisis kebijakan pendidikan, khususnya kepada Bapak Prof. Dr. H. A. Supiana, M.Ag dan Ibu Dr. Hj. Qiqi Yuliati Zakiah, M.Ag serta rekan rekan mahasiswa S3 program doktor Ilmu Pendidikan Islam Angkatan 2019.

\section{KONTRIBUSI PENULIS}

Penulis pertama ialah Asep Abdul Aziz sebagai salah satu mahasiswa S3 UIN Sunan Gunung Djati Bandung. Penulis kedua ialah Rida Nurfarida sebagai salah satu mahasiswa S3 UIN Sunung Gunung Djati Bandung. Penulis ketiga ialah Nurti Budiyanti sebagai salah satu mahasiswa S3 UIN Sunan Gunung Djati juga sebagai praktisi pendidik di Universitas Pendidikan Indonesia. Penulis keempat ialah Dr. Qiqi Yuliati Zakiah sebagai dosen pengampu mata kuliah analisis kebijakan pendidikan yang telah banyak memberikan kontribusi positif dalam menuangkan ide serta gagasan dalam tulisan in. 


\section{DAFTAR PUSTAKA}

Arlita, S. E., Ahyani, N., \& Missriani, M. (2020). Pengaruh Kompetensi Akademik dan Motivasi Guru Terhadap Kinerja Guru. Attractive: Innovative Education Journal, 2(3), 814. Google Scholar

Azis, A. (2017). Manajemen Perumusan Kebijakan Pendidikan di Pondok Pesantren AlMunawwir Komplek Q Krapyak Yogyakarta. TADRIS: Jurnal Pendidikan Islam, 12(2), 181-195. http://dx.doi.org/10.19105/tjpi.v12i2.1377

Bintari, Antik, and Landrikus Hartarto Sampe Pandiangan. 2016. "Formulasi Kebijakan Pemerintah Tentang Pembentukan Badan Usaha Milik Daerah (Bumd) Perseroan Terbatas (Pt) Mass Rapid Transit (Mrt) Jakarta Di Provinsi Dki Jakarta." Jurnal Ilmu Pemerintahan :CosmoGov 2(2): 220. Google Scholar

Costantina, Yustika Caprilin. 2018. "Model Pengambilan Kebijakan Sekolah Di SDN Grobogan 2 Madiun." Muslim Heritage 2(2): 235. Goolge Scholar

Creswell, J. W. (2016). Research design: pendekatan metode kualitatif, kuantitatif, dan campuran. Yogyakarta: Pustaka Pelajar. Google Scholar

Dewi, R. (2017). Studi Kasus Penolakan Publik Atas Kebijakan Publik. Publikauma: Jurnal Administrasi Publik Universitas Medan Area, 5(1), 6-12. https://doi.org/10.31289/publika.v5i1.1165

Darwis. 2013. "Formulasi Kebijakan Pendidikan Gratis Kabupaten Pelalawan Tahun 2013." Jom FISIP 2(13): 1-13. Google Scholar

Dunn, William N. 2003. Pengantar Analisis Kebijakan Publik. Jogjakarta: Gajah Mada University Press. Google Scholar

Dye, Thomas R. 2011. Understanding Public Policy. New Jersey: Prentice Hall. Google Scholar Iskandar, Wahyu. 2019. "Analisis Kebijakan Pendidikan Dalam Perspektif Madrasah." AlMadrasah: Jurnal Ilmiah Penididikan Madrasah Ibtidaiyyah 4(1): 1-22. http://dx.doi.org/10.35931/am.v4i1.109

Irianto, Yoyon Bahtiar. 2011. Kebijakan pembaharuan Pendidikan. Jakarta: Rajawali Press.

Irianisyah, S., Harapan, E., \& Houtman, H. (2020). Supervisi Kepala Sekolah Dalam Penggunaan Media Pembelajaran di Sekolah Dasar. Attractive: Innovative Education Journal, 2(3), 1-7. Google Scholar

Ismail, M. H., \& Sofwani, A. (2016). Konsep dan Kajian Teori Perumusan Kebijakan Publik. Jurnal Review Politik, 6(2), 195-224. Google Scholar

Lester, James P, and J Stewart. 2000. Public Policy: An Evaluation Approach . California: Wadsworth Thomson Learning.

Khoiruddin, Moh. 2016. "Analisis Kebijakan Kurikulum Pendidikan Islam Di Lembaga Pendidikan Islam." JOIES: Journal of Islamic Education Studies 1(1): 3345-56. https://doi.org/10.15642/joies.v1il.7

Masyitoh, D., Mustika, R. D., Alfaza, A. S., Hidayatullah, A. F., \& Umar Al Faruq, A. H. (2020). Amin Abdullah dan Paradigma Integrasi Interkoneksi. Attractive: Innovative Education Journal, 2(1), 108-116. Google Scholar

Meilina, Duwi, Irawan Suntoro, and Sowiyah. 2019. "Implementasi Kebijakan Pendidikan Program Bantuan Opersional Sekolah Daerah Sma Negeri 1 Kasui Way Kanan.” Jurnal 53(9): 1689-99. Google Scholar

Moser, A., \& Korstjens, I. (2018). Series: Practical guidance to qualitative research. Part 3: Sampling, data collection and analysis. European Journal of General Practice, 24(1), 918. https://doi.org/10.1080/13814788.2017.1375091

Muhdi, Muhdi, Nurkolis Siri Kastawi, and Suwarno Widodo. 2017. "Teknik Pengambilan Keputusan Dalam Menentukan Model Manajemen Pendidikan Menengah." Kelola: Jurnal Manajemen Pendidikan 4(2): 135. https://doi.org/10.24246/j.jk.2017.v4.i2.p135145

Munadi, Muhamaad, and Barnawi. 2011. Kebijakan Publik di Bidang Pendidikan.Jogyakarta: Arruzmedia. 
Mulyana, Y., Huraerah, A., \& Martiawan, R. (2019). Kebijakan pengembangan destinasi pariwisata Cianjur Selatan di Kabupaten Cianjur Jawa Barat. JISPO Jurnal Ilmu Sosial dan Ilmu Politik, 9(1), 490-511. https://doi.org/10.15575/jispo.v9i1.5857

O’Dwyer, L. M., \& Bernauer, J. A. (2013). Quantitative Research for the Qualitative Researcher. SAGE Publications. Google Scholar

Parsons, Wayne. 2006. Public Policy: Pengantar Teori dan Praktik Analisis Kebijakan. Jakarta:Kencana.

Saihu, S. (2020). Konsep pembaharuan pendidikan islam menurut fazlurrahman. Andragogi: Jurnal Pendidikan Islam dan Manajemen Pendidikan Islam,2(1), 82-95. https://doi.org/10.36671/andragogi.v2i1.76

Sabri, Ahmad. 2013. "Kebijakan Dan Pengambilan Keputusan Dalam Lembaga Pendidikan Islam." Al-Ta lim Journal 20(2): 373-79. http://dx.doi.org/10.15548/jt.v20i2.34

Suhono, S., \& Sari, D. A. (2020). Developing Students' Worksheet Based Educational Comic for Eleventh Grade of Vocational High School Agriculture. Anglophile Journal, 1(1), 2940. Google Scholar

Toha, M., \& Hilmy, M. (2020). Pendidikan Islam di Kota Metropolis: Studi Kebijakan Penyelenggaraan PAI di Surabaya. Inteligensia Media. Google Scholar

Syafaruddin. 2008. Efektifitas Kebijakan Pendidikan. Jakarta: Rineka Cipta.

Vedung, E. (2017). Public policy and program evaluation. Routledge. Google Scholar

Wahab, Solichin Abdul. 2014. Analisis Kebijkaan : Dari Formulasi Ke Penyusunan ModelModel Implementasi Kebijakan Publik. Jakarta: Bumi Aksara. Google Scholar

Winarno, Budi. 2012. Kebijakan Publik : Teori, Proses dan Studi Kasus. Yogjakarta: CAPS.

\section{Copyright Holder :}

(C) Aziz, A., Nurfarida, R., Budiyanti, N., \& Zakiah, Q. (2020)

First Publication Right :

(C) Tapis : Jurnal Penelitian Ilmiah

This article is under:

CC BY SA 